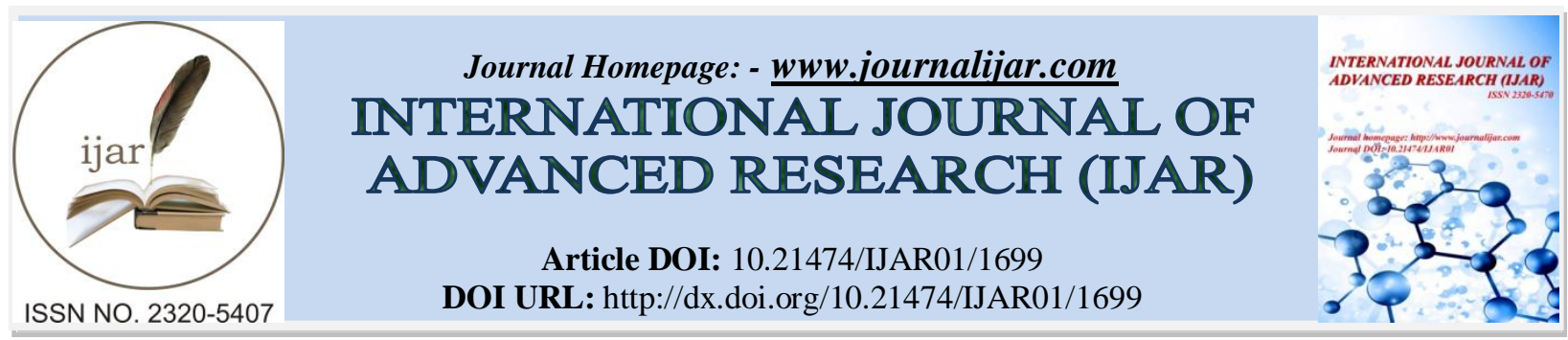

RESEARCH ARTICLE

\title{
ASSOCIATION AND UTILIZATION OF BIO-AGENTS IN MANAGEMENT OF APHID INSECT-PESTS:
} A REVIEW.

Urvi Sharma ${ }^{1}$, Surender K. Sharma ${ }^{2}$ and Suman Sanjta ${ }^{1}$.

1. Ph. D. Scholars, Department of Entomology, CSK HP Krishi Vishvavidyalaya, Palampur.

2. Scientist (Entomology), Department of Organic Agriculture, CSK HP Krishi Vishvavidyalaya, Palampur, 176062 (H.P.) India.

\section{Manuscript Info}

\section{Manuscript History}

Received: 12 July 2016

Final Accepted: 19 August 2016

Published: September 2016

\section{Key words:-}

Aphids, aphidophagous, bio-control agents, predators and parasitoids

\section{Abstract}

Aphids, the pests of worldwide economic importance cause considerable damage and yield losses in crops. In recent times, the need for ecologically compatible management strategies is in huge demand and hence for sustainable \& economically viable strategies for insect-pest management, to involve the natural agents is as an important prerequisite. Therefore, an effort has been made to highlight the association of various aphidophagous natural enemies (predators, parasitoids \& pathogens) for their successful planning and utilization with maximal expression in eco-friendly pest management.

Copy Right, IJAR, 2016,. All rights reserved.

\section{Introduction:-}

Aphids (Hemiptera: Aphididae) are among the most important insect-pests in agriculture worldwide. Among 4,700 reported species of Aphididae across the globe about 450 species have been recorded from crop plants (Blackman and Eastop, 2000). The herbivorous aphid species belong mostly to the largest subfamily aphidinae (Blackman and Eastop, 2006). The aphids suck plant sap, hamper plant growth, secrete honey-dew, aid in decreased photosynthesis due to sooty mould and ultimately reduction in yield. Almost all parts of plant i.e. roots to tender shoots are attacked. Aphids are also known vectors of more than 200 plant viruses (Hogenhout et al., 2008) causing secondary diseases in agricultural, horticultural and other agri- based professions. In India, 10-90\% yield losses to crops by aphids have been reported depending upon infestation and crop stage (Razaq et al., 2011). Their species viz. Aphis craccivora Koch, A. gossypii Glover, Brevicoryne brassicae Linn., Lipaphis erysimi Kalt., Rhopalosiphum maidis (Fitch), Acyrthosiphon pisum-(Harris), Uroleucon compositae Theobald, etc. inflict severe damage to crops. Myzus persicae Sulzer alone transmits more than 150 viral diseases in different crops including solanaceous vegetables (Cloyd and Sadof, 1998). In sugarcane, its woolly aphid, Ceratovacuna lanigera Zehntner, one of the invasive alien aphid caused epidemics in Maharashtra during the years 2002 and 2003 (Patil et al., 2007).

Commonly used insecticides against aphid insect-pests have developed resistance (Devonshire et al., 1998; Foster et al., 2007). In most terrestrial habitats, aphid colonies succumb to attack by predators, parasitoids and pathogens which are often termed as aphidophaga. Among aphid predators (killers); adults \& larvae of coccinellid beetles \& larvae of lacewings, dipteran predatory midges \& syrphids (Volkl et al., 2007). Common entomopathogenic fungi include; Deuteromycotina and Zygomycotina that cause infection to aphids through the cuticle and finally kill them (Hajek and Leger, 1994). Parasitization (endoparasitic as aphid mummies) by several species of wasps and a few dipteran flies has been reported and these are being employed in biological control programs. Larvae of these parasitoids especially wasps' complete their development in aphid, kill them and pupate within or below the 
hardened cuticle (the mummy). The adult parasitoids are free living, feed on nectar of crops while females continue sucking haemolymph of stung aphids.

At present, insecticide regulations are strict and the alternatives like biological control approaches are increasingly investigated worldwide. Keeping in view, the worldwide acceptance of organic produce, environment safety and immunity of insects, the present paper as reviewed literature would help in activating the momentum of using natural enemies against aphid insect-pests of crops. It is imperative to understand their association and further defining their use options in various insect management modules of Organic Agriculture, IPM or Sustainable Agriculture.

\section{Predators:-}

\section{Coccinellids:-}

Aphid killing ladybeetles especially of subfamilies coccinellinae \& scymninae have more than 5000 species of which 261 species of 57 genera have been reported predaceous in India (Omkar and Pervez, 2004). The predominant species in India are; Coccinella septumpunctata Linn., C. transversalis (Fab.), Brumoides suturalis (Fab.), Hippodamia variegate (Fab.), Propylea dissectas (Mulsant), Harmonia octomaculata (Fab.) and Menochilus sexmaculatus (Fab.).

\section{Syrphidae (hover flies):-}

Larvae of subfamilies viz., syrphinae, milesiinae and microdontinae are aphidophage but among them majority are syrphinae (Rotheray, 1989; Gilbert, 1993). Among 4700 syrphinae species worldwide, 312 species under 71 genera are known from the Indian subcontinent (Joshi and Balal, 2013). Most species are mostly terrestrial of which 25 per cent are aphidophagous. Adults are active, diurnal flower visitors, feed on pollen \& nectar and predaceous larvae suppress many economically important species of aphids like L. erysimi, A. craccivora, A. gossypii, M. persicae, $B$. brassicae, U. compositae., etc. (Sathe and Visherad, 2004). Among syrphid species, Episyrphus balteatus (De Geer) is recognized as the most efficient predator.

\section{Chrysopids:-}

Lacewings are polyphagous predators feed mainly on soft-bodied insects and are frequently associated with aphids.

\section{Cecidomyids:-}

Larvae of five dipteran predatory midges of genera Aphidoletes and Monobremia prey exclusively on aphids (Harris, 1973; Nijveldt, 1988). The best-known and commonly used species in biological control is Aphidoletes aphidimyza (Markkula and Tiitanen, 1985; Schelt and Mulder, 2000)

\section{Anthocorid Predatory bugs:-}

The members of the genera Anthocoris and Orius are important predators of aphids, especially on woody host plants.

Besides these, the predators, pyralidid (Dipha aphidivora) and neuropteran (Micromus igorotus) have been reported feeding on sugarcane wooly aphid and their augmentative releases in infested fields successfully controlled the aphids (Patil et al., 2007).

\section{Parasitoids:-}

Females lay eggs into aphids which after hatching (larvae) consume internal contents and transform to pupa. Adult chews out an emergence hole. The swollen parasitized aphids turn brown to gray and are called mummies. Aphidiinae, the monophyletic braconids are the major groups of specialist solitary endoparasitoids of aphids (Kambhampati et al., 2000). Their role as natural enemies of aphids in biological control programs has been established (Stary, 1970; Kavallieratos et al., 2008a \& b). Aphidiinae includes more than 55 genera and has 400 known species (Kavallieratos et al., 2001 and Aslan et al., 2004). The most predominant and commercially useful genera include: Aphidius, Praon, Diaeretiella, Trioxys, Ephedrus (Wei et al., 2005, Vollhardt et al., 2008).

Species from the Aphelinidae also specialize on aphids (Stary, 1988). This rather large Hymenoptera family contains over 1000 species in 50 genera and most are parasitoids of the Hemiptera, suborder Sternorryncha (Aleyrodoidea, Aphidoidea, Coccoidea). The genera attacking aphids are Aphelinus, Marietta, Protaphelinus and Mesidiopsis 
(Viggiani, 1984; Stary, 1988; Wei et al., 2005). All members of the Aphelinus genus are solitary koinobiont endoparasitoids of aphids.

Other aphid braconid parasitoids of aphidiinae in India have also been recently catalogued with 22 genera with 125 species (Akhtar et al., 2011). The genus Aphidius contains 21 species, represents the largest group followed by Binodoxys, Praon, Pauesia, Ephedrus \& Trioxys with 19, 12, 10, 9 \&7 species, respectively, in India (Akhtar et al., 2011).

Endaphis with six species is an only known dipteran cecidomyiid aphid parasitoids. Endaphis spp. deposit their eggs near aphid colonies, the first instar larvae search aphids and develop as koinobiont endoparasitoids but mummies are not formed. Last instar larva emerges from aphid and falls on the ground to pupate in the soil (Muratori et al., 2009).

\section{Aphid Pathogens:-}

The most common aphid entomopathogen that contribute are from order entomophthorales. The six common fungal species recorded from pest \& non-pest aphids worldwide are Conidiobolus obscures (Hall and Dunn), Entomophthora planchoniana Cornu, Neozygites fresenii (Nowak), Pandora neoaphidis (Remaud. \& Hennebert) Humber, Zoophthora phalloides Batko, and Zoophthora radicans (Brefeld) Batko - NCBI (Wilding and Brady, 1984). Fungi such as Lecanicillium (formerly classified as the single species Verticillium lecanii), Beauveria bassiana (Balsamo) Vuillemin, Metarhizium anisopliae (Metschnikoff) Sorokin and Paecilomyces fumosoroseus (Wize) are some other important pathogens associated with various aphid pests and some have been developed as commercial biopesticides ( Kim et al., 2001; Ujjan and Shahzad, 2011). A virulent isolate of M. anisopliae was reported and used in integrated pest management programme of lettuce root aphid, Pemphigus bursarius (Chandler, 1997; Parker et al., 2002). Entomophthora aphidis Hoffman has been found potential pathogen against the pomegranate aphid, Aphis punicae (Passerini) at Bangalore, India (Sreedevi et al., 2010).

\section{Using bioagents in Field:-}

C. septempunctata @ 3,000 and 5,000 beetles/ha, V. lecanii @10 spores $/ \mathrm{ml}$ have been reported to reduce 65.46, 88.17 and 75.79 per cent of mustard aphid, L. erysimi population(Singh et al., 2008); V. lecanii @ $10^{5}$ spore/ml has also been documented with the similar mortality (Parmar et al., 2008). A module based bio-control for mustard aphid consisting of release of $C$. septumpunctata @ 2000/acre + Diaeretiella rapae @2000 mummies/acre + yellow sticky traps @ 1 per $100 \mathrm{~m}^{2}$ increased yield 83 per cent than check (Firake et al., 2013). Significant reduction of $A$. craccivora populations on groundnut by using B. bassiana and P. fumosoroseus @ $10^{10}$ spores $/ \mathrm{ml}$ has also been repoted by Sahayaraj and Namachivayam (2011).

\section{Conclusion:-}

The efficient use of biodiversity in insect-pest management has become a priority in modern agriculture due to both reducing quantity and increasing cost of synthetic insecticides or insecticides' residue and resistance problems. However, some success to manage aphid insect-pests has been achieved by using wasp parasitoids, predators and fungal pathogens but extensive research on bioagents' interaction and standardized techniques are much needed.

\section{References:-}

1. Akhtar, M. S., Dey D. and Usmani M. K. (2011): A catalogue of aphid parasitoids (Hymenoptera: Braconidae: Aphidiinae) from India. In: Insecta Mundi: Center for Systematic Entomology, U. S. A. 0151: Inc. Gainesville, pp. 1-31

2. Aslan, M. M., Uygun, N. and Stary, P. (2004): A Survey of Aphid Parasitoids in Kahramanmaras, Turkey (Hymenoptera: Braconidae, Aphidiinae; and Hymenoptera: Aphelinidae). Phytoparasitica, 32(3): 255-263

3. Blackman, R. L. and Eastop, V. F. (2000): Aphids on the World's Crops: An Identification and Information Guide, $2^{\text {nd }}$ edn, Chichester: Wiley, 466 pp.

4. Blackman, R. L. and Eastop, V. F. (2006): Aphids on the World's Herbaceous Plants and Shrubs, Chichester: Wiley, $1439 \mathrm{pp}$.

5. Chandler, D. (1997): Selection of an isolate of the insect pathogenic fungus Metarhizium anisopliae virulent to the lettuce root aphid Pemphigus bursarius. Biocontrol Science and Technology, 7: 95-104

6. Cloyd R. A. and Sadof C. S. (1998): Aphids: Biology and Management. Floriculture Indiana, 12(2): 3-7 
7. Devonshire, A. L., Field, L. M., Foster, S. P., Moores, G. D., Williamson, M. S. and Blackman, R. L. (1998): The evolution of insecticide resistance in the peach potato aphid, Myzus persicae. Philosophical Transactions of The Royal Society Biological Sciences, 353: 1677-1684

8. Firake, D. M., Behere G. T. and Thakur N. S. Azad. (2013): Eco-Friendly Management of Mustard Aphid, Lipaphis erysimi: a most destructive pest of brassicaceous crops. Popular Kheti, 1(3): 31-33

9. Foster, S. P., Devine, G. and Devonshire, A. L. (2007): Insecticide resistance. In: van Emden HF and Harrington R (eds) Aphids as crop pest, Wallingford, UK: CAB International, pp. 261-286

10. Gilbert, F. S. (1993): Hoverflies. Naturalists' Handbooks No. 5, 2nd edn. Richmond Press, Slough, 72 pp.

11. Hajek, A. E. and Leger, R. J. (1994): Interactions between fungal pathogens and insect hosts. Annual Review of Entomolology, 39: 293-322

12. Harris, K. M. (1973): Aphidophagous Cecidomyiidae (Diptera): taxonomy, biology and assessment of field populations. Bulletin of Entomological Research, 63: 305-325

13. Hogenhout, S. A., Ammar, E. D., Whitfield, A. E. and Redinbaugh, M. G. (2008). Insect vector interactions with persistently transmitted viruses. Annual Review of Entomolology, 46:327-359

14. Joshi, S. and Ballal C. R. (2013): Syrphid Predators for Biological Control of Aphids. Journal of Biological Control, 27(3): 151-170

15. Kambhampati, S., Volkl, W. and Mackauer, M. (2000): Phylogenetic relationshps among genera of Aphidiinae (Hymenoptera: Braconidae) based on DNA sequence of the mitochondrial 16S rRNA gene. Systematic Entomology, 25: 437-445

16. Kavallieratos, N. G., Lykouressis, D. P., Sarlis, G. P., Stathas, G. J., Sanchis-segovia, A. and Athanassiou, C. G. (2001). The Aphidiinae (Hymenoptera: Ichneumonoidea: Braconidae) of Greece. Phytoparasitica, 29: 306-340

17. Kavallieratos, N. G., Tomanovic, Z., Athanassiou, C. G., Stary, P. and Bogdanovic, M. (2008a): Parasitoids (Hymenoptera: Braconidae: Aphidiinae) attacking aphids feeding on Prunoideae and Maloideae crops in Southeastern Europe: aphidiine-aphid-plant associations and key. Zootaxa, 1793: 47-64

18. Kavallieratos, N. G., Tomanovic, Z., Stary, P. and Emanouel, N. (2008b): Vitex agnus Castus and Euphorbia characias Wulfenii as reservoirs of Aphid parasitoids (Hymenoptera: Braconidae: Aphidiinae). Florida Entomologist, 91(2): 121-135

19. Kim, J. J., Lee M. H., Yoon, C. S., Kim, H. Yoo, J. and Kim K. C. (2001): Control of cotton aphid and greenhouse whitefly with a fungal pathogen. Bulletin, Korean National University, Kwangju, 7-14

20. Markkula, M. and Tiitanen, K. (1985): Biology of the midge Aphidoletes and its potential for biological control. In: Hussey NW, Scopes N (eds) Biological Pest Control: the glasshouse experience. Ithaca: Cornell University Press, pp. 74-81

21. Muratori, F. B., Gagne, R. J. and Messing, R. H. (2009): Ecological traits of a new aphid parasitoid, Endaphis fugitive (Diptera: Cecidomyiidae), and its potential for biological control of the banana aphid, Pentalonia nigronervosa (Hemiptera: Aphididae). Biological Control, 50: 185-193

22. Nijveldt, W. (1988): Cecidomyiidae. In: Minks AK, Harrewijn P (eds) Aphids: their biology, natural enemies and control, Vol.2B, Amsterdam: Elsevier, pp. 271-277

23. Omkar and Prevez. (2004): Predaceous coccinellids in India: predator-prey catalogue (Coleoptera: Coccinellidae). Oriental Insect, 38: 27-61

24. Parker, W. E., Collier, R. H., Ellis, P. R., Mead, A., Chandler, D., Blood Smythe, J.A. and Tatchell, G.M. (2002): Matching control options to a pest complex: the integrated pest management of aphids in sequentially planted crops of outdoor lettuce. Crop Protection, 21: 235-248

25. Parmar, G. M., Karpadia, M. N. and Davda, B. K. (2008): Bioefficacy and cumulative effect of Verticillium lecanii (Zimmerman) against Lipaphis erysimi (Kaltenbach) on mustard International Journal of Agricultural Sciences, 4: 204-206

26. Patil, A. S., Magar, S. B. and Shinde, V. D. (2007): Biological control of the sugarcane woolly aphid (Ceratovacuna lanigera) in Indian sugarcane through the release of predators. Proceeding- International Society of Sugar Cane Technologists, 26:797-804

27. Razaq, M., Mehmood, A., Aslam, M., Ismail, M., Afzal, M. and Alishad, S. (2011): Losses in yield and yield components caused by aphids to late sown Brassica napus, Brassica juncea and Brassica carrinata braun at Multan, Punjab (Pakistan). Pakistan Journal of Botany, 43(1): 319-324

28. Rotheray, G. E. (1989): Aphid Predators. Cambridge Naturalists' Handbooks, No. 7, Cambridge: Cambridge University Press, , 86 pp.

29. Sahayaraj, K. and Namachivayam S. K. R. (2011): Field Evaluation of Three Entomopathogenic fungi on Groundnut Pest. Tropicultura, 29 (3): 143-147 
30. Sathe and Visherad. (2004): Syrphids: as an important predator of aphids in India. In: Sahayaraj K (ed) Indian Insect Predators in Biological Control ,p. 261

31. Singh, Y. P., Meghwal, H. P. and Singh, S. P. (2008): Evaluation of Bioagents against Mustard Aphid, Lipaphis erysimi (Kaltenbach) (Homoptera: Aphididae), under Net Covered Condition in Field. Journal of Biological Control, 22(2):321-326

32. Sreedevi, K., Verghese A. and Vasudev, V. (2010): Occurrence of entomopathogenic fungi, Entomophthora aphidis Hoffman (Zygomycetes: Entomophthorales) in epizootic form on the pomegranate aphid, Aphis punicae Passerini. Current Biotica, 4(1): 82-88

33. Stary, P. (1970): Biology of aphid parasites (Hymenoptera: Aphidiidae) with respect to integrated control. The Hague, The Netherlands $643 \mathrm{p}$.

34. Stary, P. (1988): Aphidiidae In: Minks A.K. and Harrewijn, P eds. Aphids: their biology, natural enemies and control, Vol. 2B. New York, NY: Elsevier

35. van Schelt, J. and Mulder, S. (2000): Improved methods of testing and release of Aphidoletes aphidimyza (Diptera: Cecidomyiidae) for aphid control in glasshouses. European Journal of Entomology, 97: 511-515

36. Ujjan, A. A., and Shahzad S. (2012): Use of entomopathogenic fungi for the control of mustard aphid (Lipaphis erysimi) on canola (Brassica napus 1.). Pakistan Journal of Botany, 44(6): 2081-2086

37. Viggiani, G. (1984): Bionomics of the Aphelinidae. Annual Review of Entomology, 29: 257-276.

38. Volkl, W., Mackauer, M., Pell, J. and Brodeur, J. (2007). Predators, parasitoids and pathogens In: Emden Van $\mathrm{H}$ and Harrington R (eds) Aphids as crop pests, UK. Oxford: CAB International

39. Vollhardt, I. M. G., Tscharntke, T., Wackers, F. L., Bianchi, F. J. J. A. and Thies, C. (2008). Diversity of cereal aphid parasitoids in simple and complex landscapes. Agriculture Ecosystem and Environment, 126: 289-292

40. Wei, J. N., Bai, B. B., Yin, T. S., Wang, Y., Yang, Y., Zhao, L. H., Kuang, R. P. and Xiang, R. J. (2005). Development and use of parasitoids (Hymenoptera: Aphidiidae \& Aphelinidae) for biological control of aphids in China. Biocontrol Science and Technology, 15: 533-551

41. Wilding, N. and Brady, B. L., 1984. Descriptions of Pathogenic Fungi and Bacteria. Set 82, Nos. 812, 814, 815, 817, 820. CMI, Kew, UK. In: XXVI Congress, International Society of Sugar Cane Technologists, ICC, Durban, South Africa, 29 July - 2 August, 2007, pp. 797-804 